\title{
Waqf in Education Sector of Negeri Sembilan, Malaysia
}

\author{
Wan Kamal Mujani ${ }^{1, a,{ }^{\star}}$, Mohamad Khairul Izwan Rifin ${ }^{1, b}$ and Mohd Syakir Mohd \\ Taib $^{1, c}$ \\ ${ }^{1}$ Department of Arabic Studies and Islamic Civilization, Faculty of Islamic Studies, The National \\ University of Malaysia, 43600 Bangi, Malaysia \\ ainawan@ukm.edu.my, bizwandps@yahoo.com, c'sharkkay989@gmail.com \\ *Wan Kamal Mujani
}

Keywords: Waqf, Education, State of Islamic Council, Negeri Sembilan, Malaysia.

\begin{abstract}
Waqf has been practiced among Muslims in Malaysia since long ago. Management of waqf property in Malaysia is placed under an appointed al-mutawalli and the respective state Islamic administration. Many studies have been conducted on waqf in various sectors which multifariously benefit and contribute to the Muslim society. Thus, the prime objective of this research is to study waqf in the education sector of the state of Negeri Sembilan as well as the development of waqf property by the Negeri Sembilan State Islamic Council (MAINS), the private sector and individuals. The research method used is qualitative involving literature review and field survey. Research results find that waqf in education sector in Negeri Sembilan evidently bring many benefits and facilities, particularly to the local society and generally to the Muslim community in Malaysia. As a result of this, the state government, private sector and individuals should be jointly responsible in developing waqf property and constantly ensure that waqf contributions optimally benefit the society.
\end{abstract}

\section{Introduction}

Semantically, the term waqf connotes giving charity for public use or for Islamic religious purposes. In Arabic language, the term waqf means to stand still or stop. Another word synonymous with waqf is al-habs which means to stop or hold, whereas the word habbasa in the dictionary al-Munjid fi al-Lughah wa al-A'läm means to withhold or restrain in the path of Allah. Fiqh scholars have agreed on waqf to mean al-habs, because the connotation is closer to the Islamic sense. Waqf is also known as sadaqah jariah (continuous charity), or șadaqah al-muharramāt (inviolable charity). Whenever the word al-waqf is related to property such as land, livestock and so on, it connotes the freezing of ownership for certain purposes or benefits.

In Islamic terminology, scholars have submitted some definitions of waqf. Although there are differences in its definition among jurists (fuqaha'), in reality all the definitions are similar in principle. There are three main principles in the concept of waqf: Allah's ownership which means perpetual, extinction of waqif's ownership and benefits for mankind. According to the al-Shafi'i school of law, waqf of property is permanent holding or prohibition of property for the benefits of that property, while the property owner loses ownership. Endowment of the property is a form of charity to get closer to Allah. According to Abu Hanīfah, endowment of property connotes prohibition of corporeal property( 'ain) owned by the waqif for another party giving the benefits from that property for welfare purposes, whether for the present or future. In the view of al-Maliki scholars, waqf means prohibition from dealings by the owner, while at the same time ownership remains with the waqif and may be utilised for welfare purposes [1].

In Negeri Sembilan, the State Islamic Council or MAINS has listed the total area of waqf property consisting of general waqf and specific waqf as amounting to 14.8464 hectares. In the Seremban district alone, the total area of waqf land listed is 2.6478 hectares, in Kuala Pilah district 3.6639 hectares, in Port Dickson district 3.0800 hectares, in Jempol district 0.2569 hectares, in Tampin district 2.0790 hectares, and in Jelebu district 3.1188 hectares. The types or categories of waqf property listed are buildings, houses, flat, agricultural lands, vacant lands, learning centres, mosques, prayer places and cemeteries. MAINS is also stepping up efforts to list down as many as possible waqf 
property not yet surrendered in writing to MAINS. This endeavour is seen as a strategic step to facilitate MAINS in identifying the type of waqf property or land suitable to be developed, particularly in the form of general waqf.

Generally, the purpose of this research is to analyse the waqf contribution to the education and economic sectors in Negeri Sembilan. Osman Sabran in his study, Pengurusan Harta Wakaf (Management of Waqf Property), stated that endowed property needs to be properly managed by the government or private trustee. Good property management will result in maximum benefits to the Muslim community and the local society. Mohamad Tahir Sabit in his working paper, Innovative Modes of Financing: The Development of Waqf Property, revealed that there are thousands of acres of inactive waqf lands in Malaysia. This is due to the unequal treatment by the law and the market forces in the real estate market. All the while, waqf lands have been traditionally developed. Thus the researcher attempts to determine whether the situation is similar with waqf lands and property in Negeri Sembilan and how existing properties are developed by government institutions, private sector and individuals. According to an article by Habibollah Salarzahi et. al, it was stated that waqf is seen as an instrument for distribution of wealth through entrepreneurs in a society. Resource development is necessary but it also requires government funds. Hence, research on resource development in waqf practice is essential to identify funds available for developing waqf property. The funds obtained will enable implementation of various development projects by the authorities and thereby impact the country's economic progress.

\section{Waqf in the education sector}

Waqf institutions such as the state Islamic council, Majlis Agama Islam Negeri Sembilan (MAINS) and the waqf corporation, Perbadanan Wakaf Negeri Sembilan (PWNS) indeed emphasize on providing education to Muslims in the state of Negeri Sembilan. Education is very essential to produce a knowledgeable and intellectual society for human resource/capital development. Economists hold the view that education was an important factor in the achievement of economic growth after the Second World War. For example, among developing countries,it was found that in Africa, an education as little as four years of primary school enabled the farmers to produce a higher agricultural yield than farmers who had never been to school at all. Further, education is also essential to develop society's knowledge which in turn will influence the process of national development. Education enables a person to seek and gain employment and to select profitable work. In the process of selecting workers, employers are also inclined to recruit more educated applicants [2].

Malaysia does not lag behind in terms of waqf practice, an indication of robust mușābaqāt al-khayrät (competing in goodness) among the earlier Muslims. In fact most of the religious schools (madrasah and pondok) were founded on waqf land. The expenditure for running these institutions are also funded from the waqf, such as Madrasah Hamidiah (now Maahad Mahmud) in Kedah, Madrasah al-Sultan Zainal Abidin (now UNISZA) in Terengganu and Kolej Islam Malaya (now Kolej Islam Klang) in Selangor [18]. Based on facts discovered, waqf contributions provided education, generally to Muslims in Malaysia and specifically in Negeri Sembilan. Waqf educational institutions began with the pondok, followed by the madrasah or Arabic stream school and, later after Independence, the government took over these institutions to be administered according to the mainstream school system. Currently, the educational institutions run on waqf comprise of Sekolah Agama Rakyat or SAR (People's Religious Schools), Sekolah Agama Negeri or SAN (State Religious Schools), madrasah and pondok. As of the year 2005 there were an estimated 174 educational institutions which grew through waqf practice in Malaysia including Negeri Sembilan.

\subsection{Pusat Pendidikan al- Sa’idiyyah (Education Centre)}

One of the schools built on waqf land in Negeri Sembilan is Sekolah Rendah Islam al-Sa'idiyyah or SRIAS (al-Sa'idiyah Islamic Primary School) in Seremban. It was named after a renowned Malaysian scholar in Negeri Sembilan, the late Sheikh Haji Mohd Sa’id bin Sheikh Haji Jamaluddin. 
Around the years 1934-1950, his son, Tuan Sheikh Haji Ahmad bin Sheikh Haji Mohd Sa'id, former state Mufti of Negeri Sembilan had established an Islamic institute known as Madrasah al-Sa'idiyyah at Pondok Rasah, Negeri Sembilan. The noble efforts of Sheikh Haji Ahmad bin Sheikh Mohd Sa'id were continued by his two sons, Sahibus Samahah Dato' Haji Mohd Murtadza bin Sheikh Haji Ahmad, former State Mufti of Negeri Sembilan, as patron, and al-Hafiz Ustaz Muhamad Muhsin bin Sheikh Haji Ahmad, as principal of Maahad Tahfiz al-Quran al-Sa'idiyyah. Both of Sheikh Haji Ahmad'sons have led the administration of this center until today. The founding of Pusat Pendidikan al-Sa'idiyyah was to develop an integrated Islamic educational institution in Negeri Sembilan. It was set up as an extension to an SAR or People's Religious School, which was established in 1985.The history of this SAR began with the name Darul Falah before it became known as Sekolah Rendah Islam al-Sa'idiyyah (SRIAS). In the beginning, there was only one class of less than 10 students and a teacher, in the home of one of its founders at Golf Heights, Seremban. In the year 1992, after relocating a few times, SRIAS had constructed a temporary building on a piece of land leased from Sekolah Agama Rakyat Ampangan at Gedung Lalang. Finally, in the year 1999, after 14 years since it was formed, SRIAS constructed its own building on a piece of waqf land at Tamah Rashidah Utama, Jalan Senawang-Paroi, Seremban, Negeri Sembilan.

After the self-construction of its own building by SRIAS on the waqf land, another school, Maahad Tahfiz al-Sa'idiyyah (MTAS) was set up. The latter is a residential secondary school, which began operations in the year 2000 with a total of only 10 students. As it was built on state land, MTAS was registered Jabatan Hal Ehwal Agama Islam Negeri Sembilan or JHEINS (State Department of Islamic Affairs). The management of Pusat Pendidikan al-Sa'idiyyah have attempted to register MTAS with the Ministry of Education of Malaysia as a private school. The duration of study in MTAS is 5 years qualifying for the certificate, Sijil Tahfiz (Memorization of) al-Quran 30 juzuk (chapters). Students also sit for the Form 3 examination, Penilaian Menengah Rendah (PMR), and the Form 5 examination, Sijil Pelajaran Malaysia (SPM). The curriculum for MTAS a combination of Kurikulum Bersepadu Sekolah Menengah or KBSM (Secondary School Integrated Curriculum) and the Diniyyah Curriculum of Majlis Guru Besar Sekolah-Sekolah Islam Malaysia or MGBSIM (Malaysian Council of Islamic School Principals) [3].

\subsection{Pusat Pendidikan al-Irshad (Education Centre)}

Other than Pusat Pendidikan al-Sa'idiyyah (Education Centre), there is also Pusat Pendidikan al-Irshad in Negeri Sembilan. Pusat Pendidikan al-Irshad was known as Sekolah Agama Rakyat al-Irshad (People's Religious School). It is a private primary and secondary education cecenterntre registered with MAINS and Jabatan Pelajaran Negeri Sembilan (State Department of Education). In the year 2002, this school began to operate at a strategic location, the junction of main road Seremban-Nilai-KLIA, Batu 10 Jalan Labu, Seremban. In the draft development plan of al-Irshad, a complete education complex with learning infrastructure and economic resources is being developed based on three main concepts. The concepts applied are to make Pusat Pendidikan al-Irshad a centre for various branches of knowledge, temporal and eschatological, a centre of services for the pluralistic and multiracial society of Malaysia and as a pulse centre to mobilize the Muslim economy, specifically in Negeri Sembilan and generally in Malaysia. The objective of setting up this centre is clearly to promote waqf practice as encouraged by Islam and to give the opportunity for Muslims to jointly develop waqf practice in the education sector. Participation of the Muslim community is very much encouraged in helping to expand the use of waqf in education whereby development plans for building a more modern and comfortable al-Irshad Education Complex are still in the process [4].

\section{Summary}

Development of waqf property is not trivial or easy to implement due to their different locations and physical conditions. Further, implementation needs to comply with the conditions and procedure laid down. In spite of these challenges, MAINS and PWNS have taken steps and action to develop 
waqf property as stipulated by the waqifs so that all property may be optimally utilised to give benefits to the rightful parties in addition to developing the national economy. Obviously, economic benefits from waqf practice make for a better and more complete system of education.

The role and contributions of waqf practice by Muslims in Negeri Sembilan also have a high impact on spiritual and human advancement. Individuals from various layers of society such as scholars, aristocracy, elite and wealthy, middle class and low income are involved in waqf practice to enrich this Sunnah of the Prophet (pbuh). A high level of Islamic knowledge and consciousness on the importance of strengthening waqf in Negeri Sembilan shows that Muslims, specifically in Negeri Sembilan and generally in Malaysia, have succeeded in educating the society to strengthen waqf practice for human development which applies proper Sunnah practice. Contributions in education, economics, technology and so on succeed in attracting the interest of the Muslim community to preserve waqf practice for the purpose of Ibadah (worship) to Allah. The role of individuals and government institutions needs to be emphasized in order that existing waqf property are not left unutilised and undeveloped.

\section{Acknowledgement}

This research paper under Project 3, Sub-project A: Perception of Multi-Ethnic Community Towards Higher Education Waqf (LRGS/2013/UKM/SI/03/01) is part of LRGS Grant (LRGS/2013/UKM-UKM/SI/03). A great appreciation and gratitude to the Ministry of Higher Education of Malaysia for providing this grant.

\section{References}

[1] Badran Abu al-‘Aynayn, Ahkām al-Wașāyā wa al-Awqaf fì al-Sharī'at al-Islāmiyyah, Cairo, Dar al-Jamī’ah, 1986.

[2] Wan Kamal Mujani, Mohd Syakir Mohd Taib \& Noor Inayah Ya'akub, Educational waqf (Islamic Endowment) in Malaysia in Lecture Notes in Management Science 2014 - 2nd International Conference in Humanities, Social Sciences and Global Business Management (ISSGBM 2014), London, pp. 117-120, 2014.

[3] Wan Kamal Mujani, Pelestarian Institusi Wakaf untuk Memperkasa Pendidikan Tinggi Negara, Bangi, pp. 10-11, 2014.

[4] Wan Kamal Mujani, Pelestarian Institusi Wakaf untuk Memperkasa Pendidikan Tinggi Negara, Bangi, pp. 10-11, 2014. 